\title{
Mapping of Historical Building in Merauke uses a Geographic Information System (GIS) as a Form of Collaboration of Engineering Science
}

\author{
Yashinta Irma Pratami Hematang ${ }^{1}$ \\ Architecture Department \\ Universitas Musamus \\ Merauke, Indonesia \\ ${ }^{1}$ yashinta@unmus.ac.id
}

\author{
Izak Habel Wayangkau ${ }^{2}$ \\ Informatics Engineering Department \\ Universitas Musamus \\ Merauke, Indonesia \\ 2izakwayangkau@gmail.com
}

\begin{abstract}
Despite being located on the border area, Merauke has a very important architectural historical heritage. However, if its current existence is not well-preserved, it will lead to extinction. In fact, the historic building provides an image or identity and increases the tourism value of a city. The Old City of Merauke can be developed for tourism, similar to that in Old City of Semarang or Old City of Jakarta. Not only that, the development of the Old City area will be the first uniqueness in Papua. However, the problem experienced by the Merauke government is the absence of a Geographic Information System (GIS) that can provide information to the people of Merauke to determining the tourism potential location of the historic buildings in Merauke. GIS is also useful for the development of old building conservation research, because it serves as an initial step in conservation, the inventory phase of conservation buildings. This research is inductive exploratory research using descriptive-analytic survey method and evaluative methods.
\end{abstract}

Keywords-Merauke; historical buildings; tourism; geographic information systems; building conservation

\section{INTRODUCTION}

Based on its geographical location, Merauke Regency is on the easternmost of Indonesia's southern territory, directly adjacent to Papua New Guinea and Australia [1]. Despite being located on a border area, Merauke has a very crucial history in terms of Indonesian unity. The indigenous people of Merauke in 1963, through Pepera (Determination of the People's Opinion), decided to merge with Indonesia; whereas before, Irian mainland was made as the Dutch government's post.

This important history was witnessed by silent witnesses, such as architectural works that will become extinct if not preserved as early as possible. Since the post-Dutch government period, from 12 February 1902 to this day, there are neglected architectural works. These architectural works later became Indonesia's valuable assets. Ref [2] suggests that there are 23 historical sites designated by the Merauke Regency Office of Culture and Tourism in 2013.

Therefore, the Merauke Regency which is also a KPPN (National Priority Rural Area) has unique identity tourism potential. There is not yet tourism development in the field of building conservation through the development of old city tourist areas in any other city island of Papua. It will be the first and unique with identity for future development. Ref [3] argues that all new planning in the city must be according to the existing structure. Furthermore, ref [4] recommends that research on historical buildings must be carried out for the city of Merauke to improve local knowledge and tourism in Merauke

Ref [5] that the city needs an identity, both on an environmental scale and on a city scale. Thereby, Merauke Regency should maintain and seek the preservation of old/ historic buildings with identities. However, the development should not be literally stimulated from western culture which finds its way into Indonesia, thus Indonesian Architecture has identities, for instance a view. However, life continues and culture keeps on evolving in its time [6].

Ref [7] states that cultural heritage is a nation's cultural wealth as a form of thought and behavior of human life which is important for understanding and developing history, science and culture in the lives of the society, nation and state, so that it needs to be appropriately preserved and managed through protection, development and utilization to promote national culture for the greatest prosperity of the people.

In the background above, there are problems experienced by the Youth, Sports and Tourism Office of Merauke Regency: the absence of a Geographic Information System (GIS) that can provide information to the people of Merauke Regency on determining the location of tourism potential of the old cities' historic buildings in Merauke. For all this time, the agency informs that tourism is still in the form of leaflets, information books, and exhibitions. Dissemination of inaccessible information has not been done for tourists outside of Merauke.

The research is also useful for the development of scientific research in the field of old building conservation, because it is carried out early in the conservation field, for instance the inventory stage of buildings in need of conservation. Additional result of this research is the information on the map: the first location of the historic 
buildings, a brief description of the historic buildings, and how the preservation priority level of the historic buildings becomes a potential level category, based on building preservation criteria.

The limitation in this research is that the historical buildings mapped in geographic information systems, such as historic buildings located in Merauke Regency. In addition, the collaboration scope of engineering field is Architectural Science and Information System.

\section{RESEARCH METHODOLOGY}

The present research was inductive exploratory research, namely research with inductive approach, which is exploratory in nature. Ref [8] reveals that research with an inductive approach is that with these stages: collection of facts and formulation of theories (which is produced through the process of fact comparison). In terms of selecting research methods, this research uses descriptive-analytic survey method. Descriptive-analytical method is used to explain the condition of the research object obtained from the field surveys: observations and interviews [9]. The analysis undertaken includes identification of building condition and forms of building preservation measures.

\section{A. Data Collection}

The population was all historical buildings in Merauke Regency. The sampling technique was non-random (nonprobability). The type of nonprobability sampling technique used was purposive sampling. The data obtained on the field was not only the location coordinates of 30 historic buildings, but also information on general description, history of the buildings and descriptive condition of the building damage level. These data were then inputted, and GIS/ mapping results were generated later from the historical buildings.

\section{B. Analysis and Evaluation}

The data were analyzed using descriptive-analytical research method, starting from field observation methods and interviews, specifically for samples in need of deeper explanation. The analysis results of field observations and investigation were then inputted into the application. This research used local server, coupled with additional Xampp software, because the local host did not apply to all computers. For the evaluation of the mapping results, socialization for mapping result was conducted for target participants which in the future would become users of this application. This socialization yielded input and constructive criticism for the improvement of this application in the future.

\section{DISCUSSION}

The analysis process for the mapping begins with the data collection process. The data are collected and then processed with the following stages:

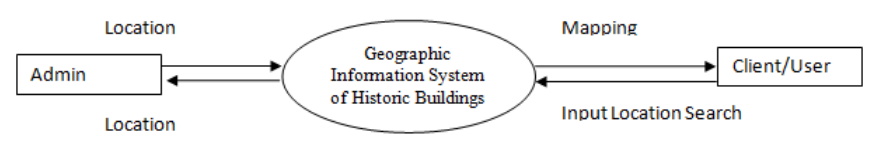

Fig. 1. System Context Diagram

Context diagram generally describes the external entities involved, the inputs needed and the output produced by the system for development. External entities in this system are Admin and Client. The admin in charge of giving input to the system and client is the system user. The input needed in this system is observation data, location and coordinates. The output generated from this system is information on the mapping of historical buildings.

\section{A. Data Collection Results}

The data collection stage is conducted through seven stages with an average of four to five architectural objects in single-day data collection. It is described below:

- Preparation Phase: it was done as a preparation stage for research work. The discussion was conducted to the entire research team. It was undertaken in Lecture Room of Musamus University's Architecture Department, and produced several items: division of labor and responsibility, determination of detailed research implementation of schedules, and other discussions supporting the activities.

- Data Collection Phase I: the first data collection phase was conducted by the team of field survey officers. The target locations of the data collection are: SD Negeri 01, SD Aperis I (SD Fransiskus Xaverius 01 and 02), Millo (SMA Jhon 23 Merauke), Protestant Churches, and all buildings behind Asmat Hotel.

- Data Collection Phase II: the second data collection phase was undertaken by the team of field survey officers. The target locations for data collection are: Shipyard/ Dock, Water Gate, Lepro (Outpatients), Lampu Satu (Lighthouse), Pal Putih (Lighthouse).

- Data Collection Phase III: the third stage of data collection phase was undertaken by the team of field survey officers. The target locations for data collection are: Theresia Dormitory (SKKP), SGA, SGB, SPG (Yos Sudarso High School) Kelapa Lima Merauke, Seminary (Pankat) Kelapa Lima, Sakra Missi.

- Data Collection Phase IV: the fourth stage of data collection phase was undertaken by the team of field survey officers. The target locations for data collection are: District's Office (Bistir Home), Rice Warehouse (Irian Bakti), CBL, Dutch Cemeteries, PBHK Nunnery (Merauke Archdiocese Complex).

- Data Collection Phase V: the fifth stage of data collection phase was undertaken by the team of field survey officers. The target locations for data collection are: Old Cathedral Church, Rectory and 
Warehouse for Pastors, and Office of Military District Commando.

- Data Collection Phase VI: the sixth stage of data collection phase was undertaken by the team of field survey officers. The target locations for data collection are: General Hospital, National Electricity Company's Service Office, Old Police Station, Artesian Wells, Merauke Penitentiary Class II.

\section{B. Data Management Modul (Client/User)}

The usage process of the website taken by the client or user is as follows:

- Home Page Display: this page is the page when users (the community or related agencies) who want to see the data on historical buildings existing in Merauke Regency. On this page, there are 2 menus: Home menu and Map Menu of the buildings.

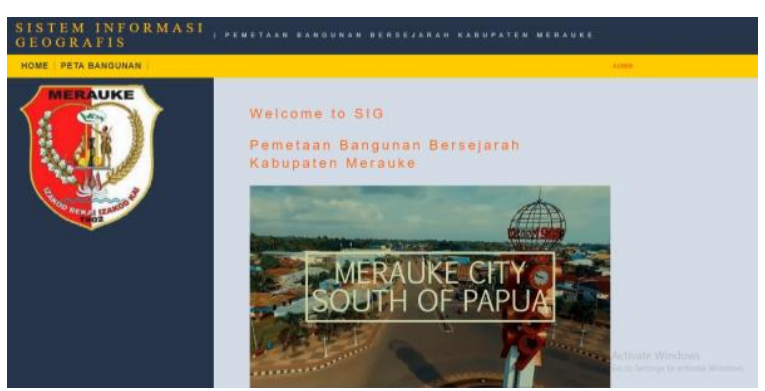

Fig. 2. Home Page Display for Users

- Page Display of Building Map: this page displays a Map of historical buildings location in Merauke Regency. Users can see the location of historic buildings and the level of preservation potential of the selected historical buildings. Users can search the data on historic buildings.

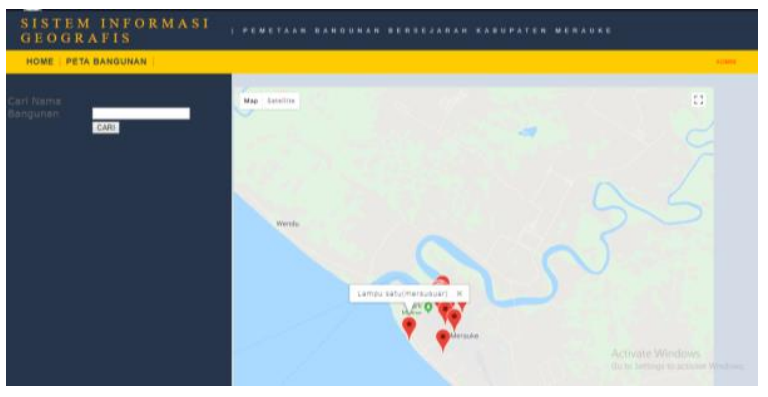

Fig. 3. Page Display of Building Map for Users

\section{Modul Pengelolaan Data (Admin)}

Display for website admin when updating the data is shown below:

- Login Display: Login display is the initial display to enter the system management page. On this page, the admin is asked to enter a username and password before entering data management page.

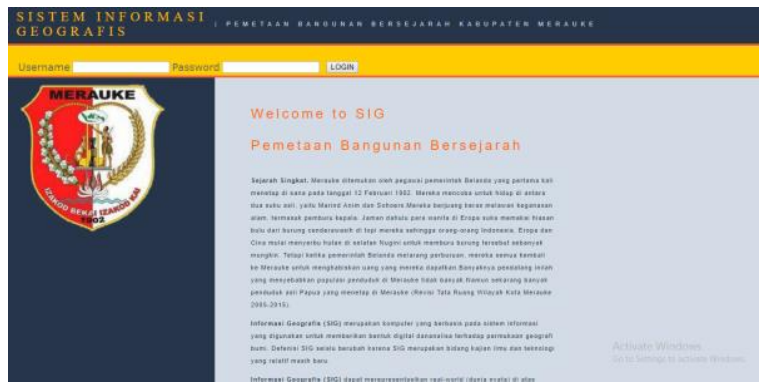

Fig. 4. Login Display for Admin

- Home Display for Admin: this display is the Home Page after the admin logged in. On this page, there are three main menus: Home menu to return to the home page, Menu map to view the mapping data of historical buildings in Merauke Regency, while the Data Menu is the page for managing historical building data in Merauke Regency.

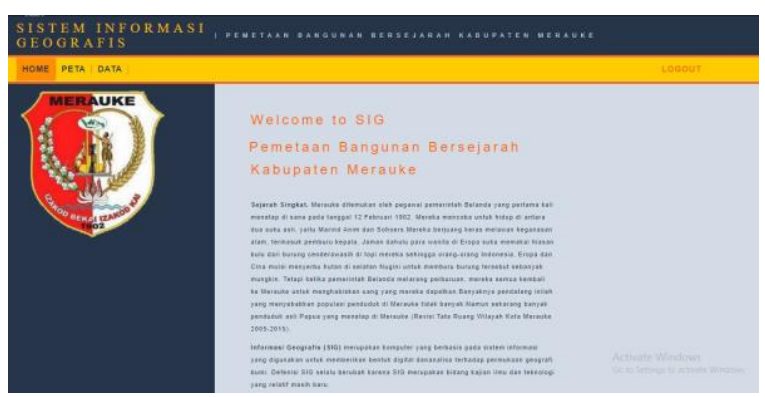

Fig. 5. Home Page Display for Admin

- Map Page Display: This page is a Map Page. On this page, the admin can see the building data and the location of the buildings in Merauke Regency.

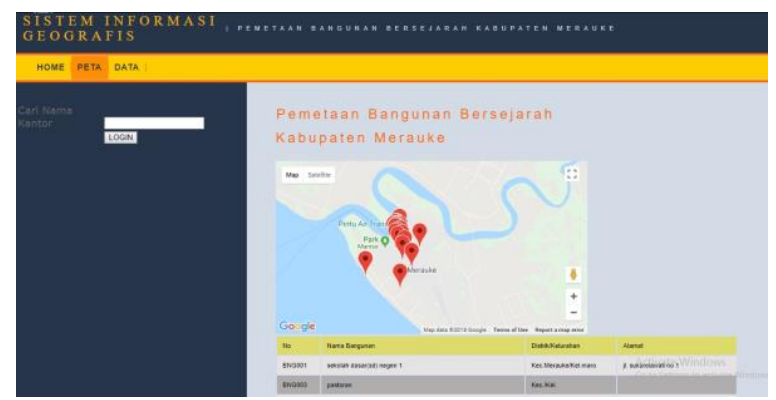

Fig. 6. Map Page Display for Admin

- Data Page Display: this page is a page for managing data on historical building in Merauke Regency. The data managed take the form of general data and architectural conservation criteria scores. On this page, the admin can see which buildings given with a criteria score or those are not. On this page, there are two menus: the building data menu for managing building data, and gallery data menu for managing photo data from the buildings inputted. 


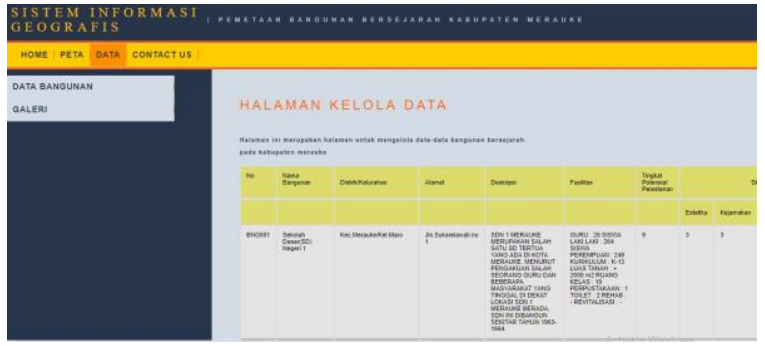

Fig. 7. Data Page Dipslay for Admin

- Building Data Page Display: this page is the page when the admin wants to manage building data, criteria score data and historical building location data, and delete $\&$ edit building data

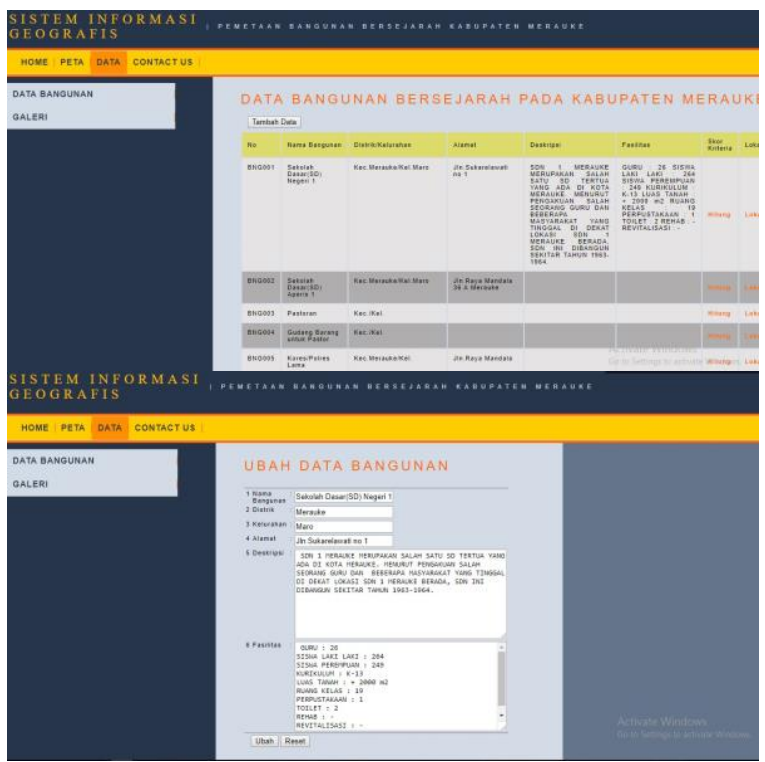

Fig. 8. Display of Building Data for Admin

- Page Display of Criteria Score Input: on criteria score input display page. If the score data does not exist, the admin is required to enter the new criteria score data, but if the score already exists, then the admin will enter the page to edit the criteria score data.

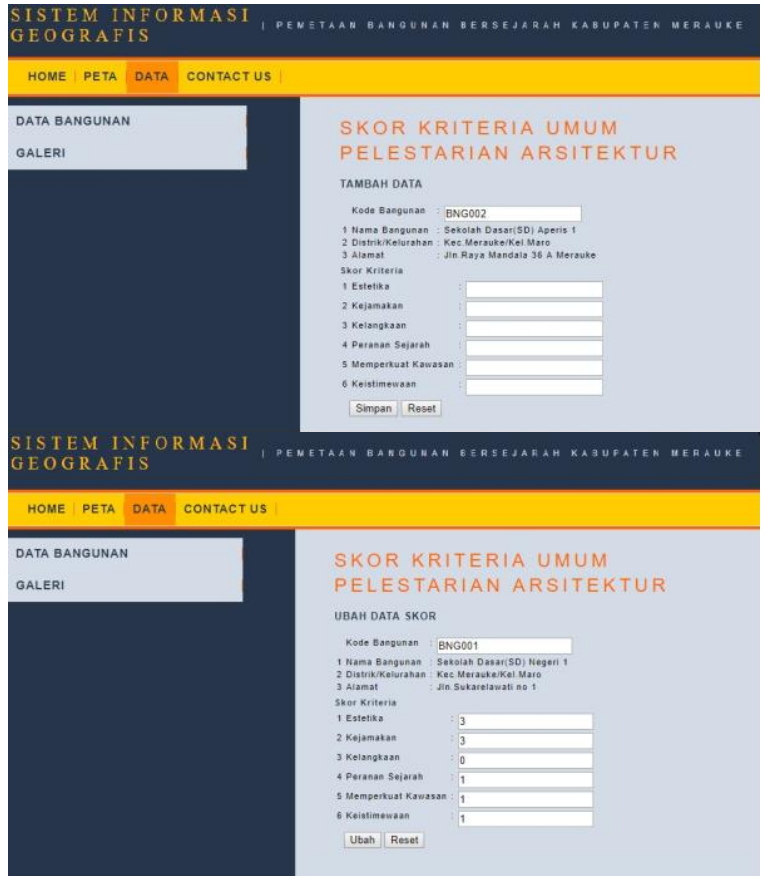

Fig. 9. Page Display of Criteria Score Input for Admin

- Page Display of Location Input: on page display of location input, if there is no location data, the admin will be required to input the new location data, whereas if the criteria score already exists, then the admin will enter the page to edit data location. On location page, the admin can input location coordinate data by entering coordinate data or shifting the marker on the map according to the location of the historical buildings.

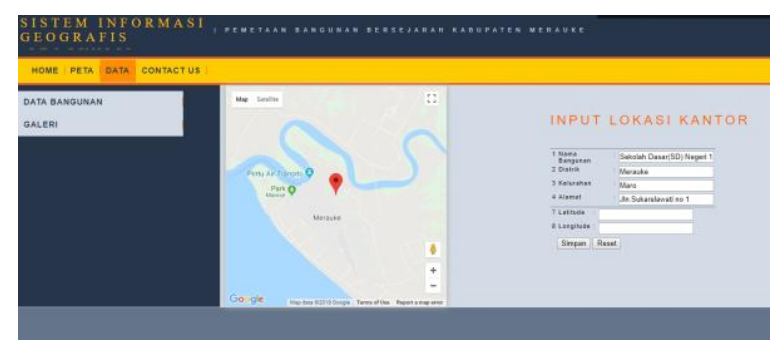

Fig. 10. Page Display of Location Input for Admin

- Gallery Data Display: the following page is a page for managing image gallery data from historical buildings. The admin can either input or delete existing image data.

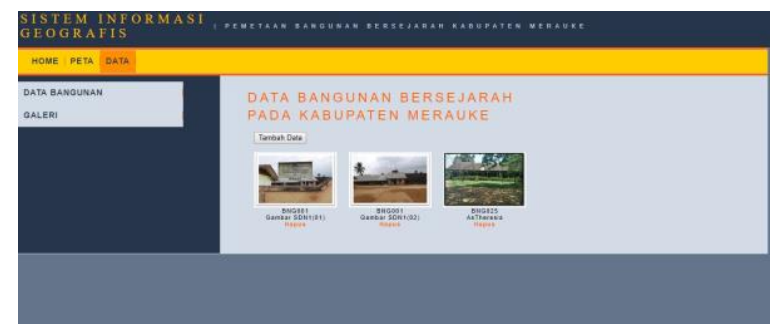

Fig. 11. Page Display of Gallery Data for Admin 


\section{Collaboration of Engineering Sciences}

Information System is an activity of many organized procedures. When implemented, it will provide information which can support the decision making and control within the organization. Meanwhile, in other meanings, Information System is a combination of people, facilities, technology, media, procedures and controls aimed at obtaining important communication channels, processing certain types of routine transactions, and giving signals to other management of internal events [10]. From the two definitions of the information system above, it can be concluded that Information System provides information to assist management decision-making; day-to-day operations of the company; and appropriate information designated for parties outside of the company.

Other engineering techniques used are architecture. Architecture is the science and art of planning and designing a built-environment, starting from the macro to the micro sphere, all of which are commonly interpreted as the science and art of the building's planning and design. The initial stage of all the design process is awareness of the problematic condition and the decision to find a solution. A designer must firstly make documentation on the condition existing in a problem, define the context, and collect relevant data for later studies and analyses [11]. Therefore, the mapping process in this research combines Information System Science and Architecture Science. Similar studies have also been carried out by [12] that carried out the development of cultural heritage with Geographic Information Systems and gamification which also developed cultural heritage in the city of Malang. In addition, there are also journals that discuss efforts to develop the concept of conservation in relation to Information Technology (IT) [13].

\section{CONCLUSIONS}

After conducting the research, there are several conclusions to obtain:

- Research collaboration of more than one scientific field is able to generate the development of each discipline.

- Mapping based on GIS (Geographic Information System) is one form of collaboration in Information System and Architectural Science.

- GIS-based mapping management module is divided into two, i.e. client/ user management module and admin management module.

- The discussion in GIS may take the form of a brief description, history, location of the mapping, coupled with criteria score for the preservation of historical buildings.

- Evaluation activities take the form of dissemination on the system for the sake of this research's development, or for the development of similar research in the future.

\section{ACKNOWLEDGMENT}

Acknowledgments were conveyed to the Rector of Musamus University and Chairperson of Musamus University Research and Community Service Institution (LPPM UNMUS), who have helped in the process of contract research activities of the Beginning Lecturers (PDP) of the 2018 Budget Year, in which funding is charged to the DIPA Directorate General of Research and Development Strengthening, Ministry of Research, Technology and Higher Education DIPA SP Number - 042.06.1.401516/2018, dated 05 December 2017, so that the research can be completed. The results of the study can finally be published in this article. In addition, the authors would like to thank all who contributed to the writing of this article, even though they were not writers.

\section{REFERENCES}

[1] Central Bureau of Statistics, "Merauke Regency in Figures," 2016.

[2] Central Bureau of Statistics, "Merauke In Figures 2014," 2014.

[3] R. Krier, Architectural composition. 1996.

[4] Y.I.P. Hematang, "Typology of the Historic Building of the Lepro Merauke House,” Mustek Anim Ha, vol. 6, no. 3, pp. 262-274, 2017.

[5] Tri Prasetyo Utomo, "Typology and Preservation of Historic Buildings," J. Seni Rupa Surakarta, vol. 2, no. 1, pp. 71-79, 2005.

[6] M. Soeroto, From Traditional Architecture to Indonesian Architecture, 2003.

[7] Law No 11 Year 2010 About Cultural Preserve, 2010, pp. 1-56.

[8] E. Setyowati, Research Methodology and Statistics, Semarang: UPT UNDIP PRESS SEMARANG, 2013.

[9] Agustinha Risdyaningsih, "Preservation of the Meeting House of the Banyuwangi City English Dormitory Complex," eJournal, vol. 7, no. 2, pp. 115-128, 2014.

[10] H.M. Jogiyanto, Information System Analysis and Design, Jakarta: Andi Publisher, 2008.

[11] Francis D. K. Ching, Architecture, Form, Space and Order, Jakarta: Erlangga, 2007.

[12] M. Alawi, F. Ramdani, and D. Pramono, "Development of Cultural Heritage Geographic Information Systems in Malang based on Webgis, 3D, and Gamification,” J. Pengemb. Teknol. Inf. dan Ilmu Komput., vol. 2, no. 4, pp. 1464-1474, 2018.

[13] B.N. Muchamad, "Model of Preservation of Information TechnologyBased Architecture Case Study: Traditional Architecture of the Banjar Tribe," DIMENSI, vol. 32, no. 2, pp. 95-101, 2004. 